\title{
'THE MADDING WHEELES OF BRAZEN CHARIOTS RAG'D; DIRE WAS THE NOISE': MOTORING AND THE ENVIRONMENT IN NEW ZEALAND BEFORE THE SECOND WORLD WAR
}

ALEXANDER TRAPEZNIK

History Programme, University of Otago

AUSTIN GEE

\section{Abstract}

The environmental impact of motor vehicles is not a recent phenomenon, it was evident from their earliest years. This was the case in New Zealand, a relatively small though urbanised society, which took up car and motorcycle ownership at a high rate from about 1910 on. This article examines three aspects of the impact of motoring: air, noise and visual pollution. Each was an existing problem to which motor vehicles added a new aspect. As was the case elsewhere, dust diffusion was a greater concern than exhaust emissions in the early decades of the twentieth century. Second, the sound of car horns and vehicle exhausts prompted widespread complaints that fed into a wider international debate on the nature of urban noise and its effect on public health. In addition, traditional social relations were felt to have been upset by antisocial noise. Third, private motoring was blamed for the spread of rural visual pollution since it encouraged roadside advertising. The campaign against billboards revealed much about attitudes towards the picturesque and the commercial use of the countryside. Together with concerns about air and noise pollution, this formed part of a wider early twentieth-century anxiety about the progress of modernity.

Keywords: New Zealand, environment, motor vehicles, cars, motorcycles, pollution, noise, scenery 


\section{Introduction}

This article explores changing perceptions of how private motoring, both motor cars and motorcycles, affected the environment, not only physically but also audibly and visually. It seeks to avoid the compartmentalisation of motor cars and motorcycles; in the early decades, the term 'motorist' was used indiscriminately to mean both a motor car driver and a motorcycle rider. In contrast to cars and their owners, the culture of motorcycling has been little studied. ${ }^{2}$ As this article will show, perceptions of the impact of motor vehicles on the environment help undermine the 'diffusionist' interpretation of early motoring that has attracted criticism in recent years, not least from the historian Gijs Mom. This sees the United States as the basic model for 'automobilism'. Developments there, such as the democratisation of car ownership, were followed by European countries with a delay of as much as several decades. ${ }^{3}$ Mom argues that, on the contrary, all major motoring conflicts and controversies took place at more or less the same time. ${ }^{4}$ The New Zealand experience with regard to the environmental impact of motoring confirms that there was little or no lag, though naturally the scale differed.

While today the impact of motoring on the environment is often seen in terms of emissions and congestion, in its early decades, concerns were different. Dust, noise and visual pollution resulting from the spread of motor vehicles were the main concerns; the fumes they gave off constituted far less of a problem. In cities, early motor vehicles joined a range of other polluting modes of transport: smoke from railways, noxious waste from horses, noise from trams. What attracted the attention of contemporaries was not so much the pollution caused by motor vehicles as what were seen as novel 'nuisances'. Unmuffled exhausts, for instance, attracted sustained criticism as they intruded in places and times when previously there had been an expectation of relative quiet. As early as 1904, a Canterbury newspaper complained 'the evil-smelling, evil-sounding machines are becoming an unmitigated nuisance'. 5 Concerns regarding the noise of motor vehicles fitted into an international 'age-ofnoise narrative' that formed part of a wider early twentieth-century 'anxiety about the progress of modernity'. 6

There is a dearth of scholarly study of the impact of early motoring in New Zealand. The principal popular works remain Pam MacLean and Brian Joyce's The Veteran Years of New Zealand Motoring and John McCrystal's 100 Years of Motoring in

\footnotetext{
2 Gijs Mom, Atlantic Automobilism: Emergence and Persistence of the Car, 1895-1940 (New York and Oxford: Berghahn, 2015), 83

3 ibid., 13; Mom excludes Australia from his synthesis: $41 \mathrm{n} 4$.

ibid., 27.

Lyttelton Times (Christchurch), 23 November 1904, 6.

James G. Mansell, The Age of Noise in Britain: Hearing Modernity (Urbana: University of Illinois Press, 2017), $4-5$.
} 
New Zealand. ${ }^{7}$ The literature on the impact of motoring and roads on the natural and built environments is in contrast well developed in the United States, for the later twentieth century in particular. It includes, for example, Christopher W. Wells' Car Country and Jane Holtz Kay's Asphalt Nation. John R. Meyer and José A. Gómez-Ibáñez' Autos Transit and Cities looks at the postwar period, while Peter Freund and George Martin's The Ecology of the Automobile considers the sociology of automobility. Ian F. Spellerberg's Ecological Effects of Roads includes some New Zealand examples, but only from recent decades. This article is intended to address and expand upon a subject touched on by Ben Schrader in his important recent work of urban history, The Big Smoke: New Zealand Cities 1840-1920.8

Motor cars first appeared in New Zealand in 1898 and from about a decade later became increasingly commonplace. Their numbers grew rapidly, especially from about 1910, when there were approximately 3,500 motor vehicles of all types for a population of almost a million. ${ }^{9}$ By 1925 there were 71,403 motor cars, or one for every 17 people; a decade later, the ratio had reached one to 11 , one of the highest levels of car ownership internationally. ${ }^{10}$

\section{Air pollution}

Early motor vehicles entered an urban environment that already contained many other sources of air pollution. Virtually all businesses and private homes relied on coal, wood or oil for power and heating. In both urban and rural areas, dust was a significant problem in dry conditions. The dust 'nuisance' associated with motor vehicles was a development of an existing problem rather than an entirely new one. Wind-borne dust had been a nuisance from at least the mid-nineteenth century,

7 Pam MacLean and Brian Joyce, The Veteran Years of New Zealand Motoring (Wellington: A. H. and A. W. Reed, 1971); John McCrystal, 100 Years of Motoring in New Zealand (Auckland: Hodder Moa Beckett, 2003).

8 Christopher W. Wells, Car Country: An Environmental History (Seattle, WA, and London: University of Washington Press, 2012); Jane Holtz Kay, Asphalt Nation: How the Automobile Took Over America, and How We Can Take It Back (New York: Crown, 1997); John R. Meyer and José A. Gómez-Ibáńez, Autos Transit and Cities (Cambridge, MA, and London: Yale University Press, 1981); Peter Freund and George Martin, The Ecology of the Automobile (Montréal and New York: Black Rose, 1993); Ian F. Spellerberg, Ecological Effects of Roads (Enfield, NH, and Plymouth, Devon: Science Publishers, 2002); Ben Schrader, The Big Smoke: New Zealand Cities 1840-1920 (Wellington: Bridget Williams Books, 2016). For an overview of the environmental history of urban New Zealand, see Eric Pawson, 'On the edge: making urban places', in Making a New Land: Environmental histories of New Zealand, new ed., ed. Eric Pawson and Tom Brooking (Dunedin: Otago University Press, 2013), 226-40.

9 'Road Transport: The Motor Age', in An Encyclopaedia of New Zealand, ed. A. H. McLintock (Wellington: R. E. Owen, Government Printer, 1966), in Te Ara-The Encyclopedia of New Zealand, www.TeAra.govt.nz/en/ 1966/road-transport/page-2, accessed 25 November 2019; Results of a Census of the Dominion of New Zealand, 30 December 1912, www3.stats.govt.nz/historic_publications/1911-census/1911-results-census.html, accessed 25 November 2019.

10 'Motor-Vehicles Act', in The New Zealand Official Year-Book, 1926 (Wellington: Government Printer, 1926), www3.stats.govt.nz/New_Zealand_Official_Yearbooks/1926/NZOYB_1926.html, accessed 25 November 2019; Alexander Trapeznik and Austin Gee, 'Accommodating the motor car: Dunedin, New Zealand, 1901-30', Journal of Transport History 38, no. 2 (2017): 3. 
especially in dry, windy regions such as Canterbury. The dust on urban roads was considered an important hazard to public health as it contained the dried, powdered residue of animal faeces. In the early 1900s, the 'poisonous bacilli' it contained were blamed for anything from quinsy to enteric catarrh. ${ }^{11}$ Overseas experience primed New Zealanders to anticipate a problem thrown up by the advent of motor vehicles. Horses' hooves, and the narrow, metal-rimmed wheels of the vehicles they drew, disturbed comparatively little dust. The wider, pneumatic rubber tyres of even the earliest, low-powered cars threw up a great deal more. Initially, the reasons for the difference were a mystery to contemporaries, but experimentation indicated the suction effect of the flexible tyre tread, combined with the movement of air around the car's bodywork, was responsible. ${ }^{12}$ At higher speeds, car tyres sucked out the fine binding material from a macadamised road surface, allowing the coarser metalled surface to break up. ${ }^{13}$ Experiments were conducted to find a durable, inexpensive road surface that would withstand motor traffic. Concrete was used in some cases, but the solution eventually adopted on a large scale was to coat the macadam with a layer of tar or bitumen. This meant the road no longer drained well when wet, rendering the surface slippery, especially for horses. In general, throughout this period only the busiest urban roads were sealed in this way. Unsealed roads continued to be watered by local authorities in dry weather to reduce the disturbance of dust. ${ }^{14}$ Some discovered that seawater was a more effective binder than fresh water, though the reason was poorly understood.

Passing references to the dust nuisance show it was pervasive, but there was surprisingly little complaint about dust raised by motor vehicles specifically. As was often the case with public controversies, New Zealanders were well aware of developments overseas through the reprinting of reports from newspapers and periodicals, usually British. These heightened public sensitivity to incipient signs of similar problems developing in New Zealand. Early motorists were concerned with dust mainly in so far as it affected them directly. In 1905 an Otago newspaper cycling and motoring columnist declared:

One has only to see [a] big car going along the road to understand why so much fuss is made at Home and on the Continent about the dust nuisance. The cloud of dust raised was blinding, and though it did not affect the occupants very much, it would be decidedly I unpleasant, if for anyone to attempt to travel in their rear. ${ }^{15}$

11 'Motor Cars and Public Health', Progress (Wellington), 2 November 1908, 29; see also City of Dunedin, N.Z., Report Presented to His Worship the Mayor and Councillors of the Municipal Council of the City of Dunedin, by $R$. W. Richards ... Town Clerk (Dunedin: Evening Star, 1907), 16-17.

12 See for example 'Cycling Notes', Cromwell Argus, 18 January 1909, 6.

13 Wells, Car Country, 76.

14 See Schrader, The Big Smoke, 394. The situation in American cities was similar: Brian Ladd, Autophobia: Love and Hate in the Automotive Age (Chicago: University of Chicago Press, 2008), 69-70.

15 'Demon', 'Cycling Notes', Otago Witness (Dunedin), 8 February 1905, 55, reprinted as 'The Pedaller', 'Cycling', Otago Daily Times (Dunedin), 9 February 1905, 10. 


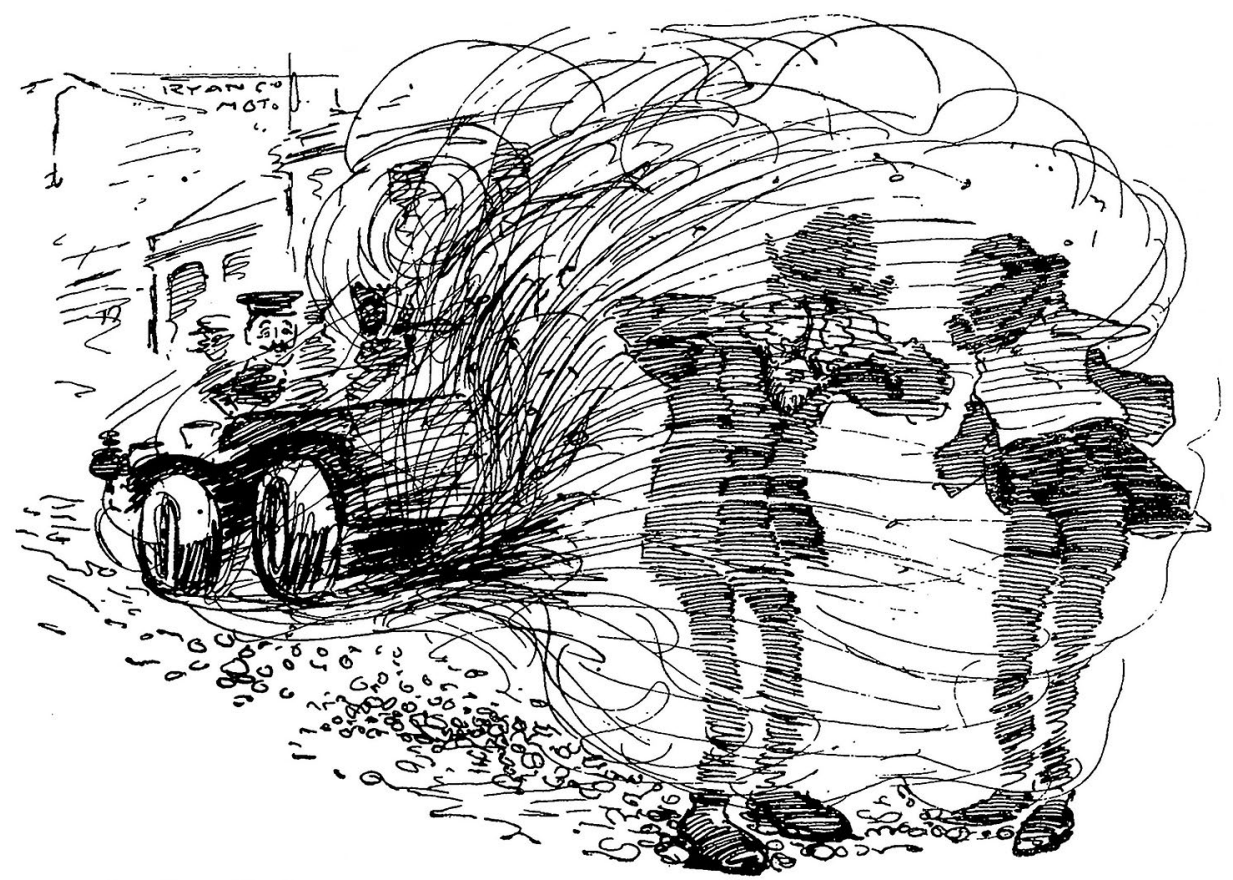

Cuty Councillor (on city street): Those beastly electric tram cars are a curse to our city. We never had any dust until they came.

Ratepayer: But there's no tram cars in this street.

Figure 1: 'The Dust Nuisance-Some Humours from the Cloud' (detail).

Source: The New Zealand Observer (Auckland), 22 December 1906, 12.

Dust on country roads was a major source of complaint in Britain. An English visitor to the antipodean Canterbury in 1909 reassured readers of The Press that 'the evils of the motor car here are mild compared with the conditions that exist at Home', where along rural

roads infested with the motor cars ... it is impossible for the inmates to open doors or windows without having everything in the house covered with a thick coating of dust, while the hedges and garden vegetation appears as though it had been sprayed with Portland cement.

The 'crops of hay and clover grown on the roadside are becoming valueless owing to their being charged to the dust and grit ... Many valuable horses have been lost, and others made seriously ill, owing to having been fed on this dust-charged hay'. ${ }^{16}$ The Times claimed the reduced numbers of flowers in London parks in the early 1920s was 'an unexpected result of motor traffic.' Even powdered horse dung was

16 'A Visitor from Lancashire', 'The Modern Menace', The Press (Christchurch), 21 June 1909, 3; see also 'Motor Tyranny', Poverty Bay Herald (Gisborne), 21 November 1906, 5; and Sean O'Connell, The Car and British Society: Class, Gender and Motoring, 1896-1939 (Manchester: Manchester University Press, 1998), 163, 166. 
thought preferable to the fine dust generated by tarred road surfaces, which 'settles on the beds which used to be gay with flowers, chokes mechanically the breathing pores of the leaves, and blights the growth as if it were weed-killer'. ${ }^{17}$

Nothing as extreme appears to have been experienced in New Zealand, initially at least. A Southland newspaper reported in 1908 that the great bulk of the farmers do not view with any alarm the increasing use and speed of the motor. It is only occasionally, and under great provocation, that they protest against motor traffic'. ${ }^{18}$ However, some farmers in the vicinity of major towns objected that they 'get no benefits from the motors, and setting aside the damage they do to the roads, they damage growing crops and hay with dust. It is almost impossible to fatten stock in any paddocks near the main roads, the cars disturb them so much. ${ }^{19}$ By the start of 1914, the 'enormous traffic of motor-cars' from Wellington was blamed for the 'deplorable state' of formerly good arterial roads to the city's north: 'Crops growing near the roads throughout Wairarapa are seriously affected with dust due to the motor traffic. ${ }^{20}$ Looking back on this period from the early 1930s, one Automobile Association member claimed that farmers who objected to the nuisance of dust clouds, once they acquired a car of their own, 'changed their attitude about the dust, holding that it did good and helped lighten the heavy soil in some districts. ${ }^{21}$

In contrast to the dust they disturbed, the emissions from motor vehicles were rarely considered a problem, except as a potential danger to their owners. Indeed, in the early years so little was known about the nature of motor fumes that they could be seen as a positive health benefit. In 1908, the popular science magazine Progress reprinted the opinion of an unnamed Harley Street specialist that the unpleasant smell of motor exhausts was 'a blessing in disguise'.

[It] is one of the finest disinfectants going. It clears the air of all germs and impurities. Partially-burnt, carbonised matter is a splendid antiseptic. The creosote vapours which come from a motor car are in reality a health tonic and a brace for the day ... It would not do the city man any harm to have several good whiffs of this smell every morning. ${ }^{22}$

Most, however, were far less sanguine.

Shortly before the First World War, several well-publicised cases spread awareness of the dangers of car exhausts in confined spaces, particularly private garages. The syndrome was briefly named 'motocide', but the significance of the colourless,

17 'Flower Beds Ruined by Tarred Roads', Northern Advocate (Whangarei), 25 April 1921, 1.

18 'The Motor and the Farm', Clutha Leader (Balclutha), 17 January 1908, 7.

19 'Mangere Ratepayer', 'Motorists and the Roads', New Zealand Herald (Auckland), 9 November 1912, 10.

20 'Town and Country', Lyttelton Times, 3 January 1914, 10.

21 'Motoring Pioneers: Early Days Recalled', Poverty Bay Herald, 9 July 1932, 4.

22 'Motor Cars and Public Health', Progress, 2 November 1908, 29; see also Tom McCarthy, 'The Coming Wonder? Foresight and Early Concerns about the Automobile', Environmental History 6, no. 1 (2001): 55. 
odourless gas carbon monoxide was not widely recognised until the 1920 s. $^{23}$ The dangers of vehicle emissions in large cities overseas were widely reported in the New Zealand press, but with the assurance that there was no danger locally. The vastness of the atmosphere, together with the windiness of most New Zealand cities, was believed sufficient to remove any danger. Complaints in the press about vehicle emissions were not common. One reader, objecting in 1928 to the physical danger, noise and 'unmitigated nuisance' of motor cars, added in passing that 'the pure air is often poisoned by the noxious fumes which are sometimes permitted to pour from the exhaust pipes of this "abominable" invention of modern days. ${ }^{24}$ Once the danger of carbon monoxide was generally recognised, concerns began to be expressed about the longer-term effects of vehicle emissions. The 'emission of smothering oil fumes and petrol gases that pollute the atmosphere and pollute human lungs' led one editorial writer in 1933 'to wonder how much longer, and how much more, the atmospheric envelope of the earth can absorb these noxious outpourings'. ${ }^{25}$ No prosecution for excessive emissions is known for this period in New Zealand, though there are examples as early as 1910 for Australia, when a Melbourne motorist appeared in court for allowing 'an excessive amount of smoke to issue from [his] car' $^{26}$

Fuel and oil were obvious sources of environmental pollution, and were subject to well-established municipal government measures controlling dangerous goods. Motor garages, many of which provided parking, stored fuel and oil on their premises, and in the 1920s began to install petrol pumps on the pavements outside. Garage petrol and grease tanks were prone to leak into the sewers, and on occasion the fumes could be strong enough to force even the sewer cleaners out onto the surface. ${ }^{27}$ The Otago branch of the Society for the Prevention of Cruelty to Animals complained that motorists used oily cans to take water from horse troughs and so were contaminating the animals' drinking water. ${ }^{28}$ The road surface itself could cause environmental harm. Early experiments in England in using coal tar and a solution of calcium sulphate produced 'evil results' when 'the chemicals were washed into the river and poisoned all the fish'. ${ }^{29}$ More than a decade later, the problem had not been

\footnotetext{
23 Though there had been earlier warnings: see McCarthy, 'The Coming Wonder?', 56-7; Ladd, Autophobia, 70.

24 'Tangatahaere', 'Motor Traffic', Otago Daily Times, 28 December 1928, 2.

25 'Noise and Noxious Fumes', Northern Advocate, 28 December 1933, 4.

26 'Warning to Motorists. Emission of Smoke', Southland Times, 22 June 1910, 3; prosecutions began in Britain in 1931: see 'Smoke From Car', Evening Star, 23 November 1931, 13.

27 See, for example, Boyd, Drainage Engineer, 'Petrol in Sewers', 31 January 1923, 1 February 1923. CE2/3/50 1919-28 PAC-PIN. Dunedin City Council Archives.

28 Minutes of Otago Motor Club 1928-32, 14 June 1932. A.A. Otago records, 95-056 1/9. Hocken Collections, Otago University, Dunedin.

29 'A Visitor from Lancashire', 'The Modern Menace', 3. For an assessment of the problem of chemical run-off from roads in recent decades in a range of developed countries, see Spellerberg, Ecological Effects of Roads, 109-12. For the late twentieth-century United States, see F. Kaid Benfield, Matthew D. Raimi and Donald D. T. Chen, Once There Were Greenfields: How Urban Sprawl is Undermining America's Environment, Economy, and Social Fabric (New York and San Francisco, CA: Natural Resources Defense Council, 1999), 78-83.
} 
solved: along country roads, 'coal-tar oils washed into the streams have poisoned the fish. The effect on vegetation can be seen along the edges of the road where spraying of tar or its hot fumes have killed the herbage'. ${ }^{30}$ In New Zealand, these fears were eventually dismissed on the grounds that the refining process used locally removed the dangerous chemicals, and in any case 'the dilution of any possible poison was so complete that the chances of damage to fish life was infinitesimal'. ${ }^{31}$

\section{Unnecessary noise}

Urban noise, like dust, was an existing environmental problem to which motor vehicles added a novel component. In this case, however, a small amount of pollution was not easily dismissed. Existing attitudes and expectations were applied to the noise of motor cars and, especially, motorcycles. A distinction was drawn between necessary or unavoidable noises and unnecessary ones. Objectionable noise was in part defined as one that occurred in the wrong time or placeunpredictable rather than predictable. 'As a matter of fact a noise nuisance is just as real and just as obnoxious as a smoke nuisance, a smell nuisance, or any other abomination', observed a Hastings newspaper in $1914 .{ }^{32}$ An apparently short-lived Noise Abatement Society, formed in Auckland in early 1935, gave radio talks on 'Unnecessary Noise'. ${ }^{33}$ While it was accepted that industrial and business districts were noisy in daytime, there was a widespread expectation that even cities would be quiet at night, and residential areas quiet at all times. Motor vehicles, especially motorcycles, broke this unwritten rule. As the historian Karin Bijsterveld points out, 'noise as "unwanted sound" has much in common with dirt as "matter out of place". ${ }^{34}$ The controversy regarding noise entailed wider social assumptions regarding respectability and civility, and attitudes towards the behaviour of the young, especially young men. Bijsterveld further explains that the 'right to make noise, as well as the right to decide which sounds are allowed or forbidden, has long been the privilege of the powerful'. Young men riding noisy motorcycles late at night upset a 'deeply-rooted cultural hierarch[y]', functioning as a 'symbol of disorder'. ${ }^{35}$

\footnotetext{
30 'Flower Beds Ruined by Tarred Roads', Northern Advocate, 25 April 1921, 1.

31 J. F. Holloway, 'Tar and Fish', Evening Post (Wellington), 1 October 1924, 9. It appears that New Zealand roads were not salted in winter, so the problem of run-off polluting groundwater, recognised elsewhere in the 1980s, did not arise. For the United States, see Jane Holtz Kay, Asphalt Nation, 90-1; and John Stilgoe, 'Roads, Highways, and Ecosystems', part 5, in The Use of the Land: Perspectives on Stewardship, nationalhumanitiescenter.org/tserve/ nattrans/ntuseland/essays/roadse.htm, accessed 12 November 2019.

32 'Street Noises', Hastings Standard, 3 January 1914, 4.

33 Auckland Star, 2 October 1936, 14; see also D. M. Aley, Hon. Secretary, Noise Abatement Society, 'Noise Abatement: Vigorous Action Needed', Auckland Star, 1 April 1935, 6.

34 Karin Bijsterveld, 'The Diabolical Symphony of the Mechanical Age: Technology and Symbolism of Sound in European and North American Noise Abatement Campaigns, 1900-40', Social Studies of Science 31, no. 1 (February 2001): 42; see also the editorial 'Noise and Nuisance', Otago Daily Times, 5 January 1928, 8. For the situation in the United States by the 1970s, see Meyer and Gómez-Ibánez, Autos Transit and Cities, 172-6.

35 Bijsterveld, 'The Diabolical Symphony', 42-4.
} 
By the mid-1920s traffic noise, particularly from car horns and motorcycle exhausts, prompted several disquisitions on human perceptions of noise. In one discussion of the topic widely reprinted in the New Zealand press, the Harley Street specialist Leonard Williams argued that a

noise, however unpleasant, which is recognised by the subconscious as necessary or inevitable, is immediately accepted and discounted, whereas a noise which is unnecessary or impertinent is rejected by the subconscious and immediately becomes an irritant of the most superlative degree.

While daytime 'noises are for the most part inevitable ... [t] his is not true of the noises which keep you awake at night'. Williams thought there was no excuse 'for the bounder who Klaxons his fiery way through streets in residential quarters at 4 a.m. ... It is the very Billingsgate of motor language'. ${ }^{36}$

A wider debate developed internationally concerning the effects of noise on productivity and public health. In New Zealand, this seems to have centred on urban areas, probably because the country, by international standards at the time, was relatively highly urbanised. The 1916 census had showed the urban population to outnumber the rural for the first time, and by 1921 the four largest cities alone accounted for 36 per cent of the population. ${ }^{37}$ Much concern was expressed by medical specialists and the public more generally, both in New Zealand and elsewhere, regarding the effect of motoring noise on the sick, and measures were taken to reduce its impact near hospitals. ${ }^{38}$ The noise of large cities was thought 'largely responsible for so much neurasthenia and general nervous instability, and for impairing not only ... health, but also general working efficiency'. ${ }^{39}$ Nervous exhaustion or neurasthenia, brought on by the strain of modern life, had been a widely accepted medical diagnosis since the late nineteenth century. Men engaged in intellectual activity were thought particularly susceptible to neurasthenia brought on by noise. ${ }^{40}$ Some medical authorities claimed further 'that the noises on modern roads are most harmful to sufferers from gout and heart complaints'. ${ }^{41}$ Noise from motor vehicles was often seen as an urban problem, but it was not confined to the larger cities; complaints came from small towns and rural communities as well. ${ }^{42}$ A large amount of traffic was not needed to cause a disturbance: even a single noisy

36 Dr Leonard Williams, 'The Tyranny of Noise', Dunstan Times, 20 September 1926, 7, reprinted from the Empire Review.

37 Statistics New Zealand, 'Historical Context', archive.stats.govt.nz/browse_for_stats/Maps_and_geography/ Geographic-areas/urban-rural-profile/historical-context.aspx, accessed 31 January 2020; Schrader, The Big Smoke, 366.

38 Bijsterveld, 'The Diabolical Symphony', 51.

39 'Noises of Sydney. Effect upon Inhabitants. Developing Loud Voices', New Zealand Herald, 21 September 1928, 11.

40 Mansell, The Age of Noise, 30, 36-7.

41 'The Noise Nuisance', Otago Daily Times, 16 May 1929, 10.

42 'Motor-Cycling: Silence First', New Zealand Herald, 13 November 1926, 36 (Kaitaia); Patea Mail, 16 March 1931, 3 (Kakaramea); 'Noisy Nights', North Canterbury Gazette, 22 February 1935, 5 (Rangiora). 
motorcyclist at night was sufficient. Motorists sounding horns caused considerable annoyance in urban centres and eventually prompted government intervention in the late 1930s. Noise abatement campaigns overseas attracted much attention in the New Zealand press, but no similar organised action was taken locally.

Intermittent complaints about the noise from unmuffled motor exhausts and the sounding of horns became a great deal more frequent in the course of 1913. Two years earlier, several reports from London of the noise caused by motor vehicles alerted the urban New Zealand public to the coming problem:

Life in London at the present time is barely tolerable owing to the everlasting series of hoots and toots, shrieks, wails, barks, grunts, coughs, post-horn gallops and 'cut-out' volleys that torture our ears by day, banish sleep by night, and scare us out of our wits at cross-roads and turnings.

The example of cities overseas considered especially noisy-Sydney, Paris, Chicago, Havana-was held up as a warning to New Zealanders. Even before the outbreak of war, the noise of motor exhausts was routinely likened to the sound of gunfire: "the pom-pom-like volleying of the "cut-out" of big cars or the Maxim gun patter-patter-patter of small ones' ${ }^{43}$ Years after the war's end, a Dunedin resident complained that motorcycles 'create a noise like that of a field battery in action'; ${ }^{44}$ they made a 'row worse than anything I heard in France', according to one old soldier. ${ }^{45}$ The exhaust cut-out, a valve that bypassed the exhaust silencer in order to reduce back-pressure on the engine in the mistaken belief that it would extract more power, was considered a particular nuisance. Motorcycles, with their two-stroke, air-cooled engines, were inherently noisier than most motor cars. When in 1912 the Post Office in Wellington began to collect the mail by motorcycle, complaints about the noise soon appeared: they were a 'perfect nuisance ... People are constantly awakened by the hubbub caused by these machines, and in neighbourhoods where sick people are lying the effect must often be serious'. ${ }^{46}$ In 1926, one Palmerston North borough councillor claimed that the 'noise from a motor cycle exhaust could quite conceivably kill a person seriously ill'. ${ }^{47} \mathrm{~A}$ Nelson resident complained that he had 'suffered intensely from [the] horrible infliction' of motorcycle noise day and night, leading to his insomnia: 'my health has given way altogether. And all this through the hateful disregard of the feelings of others by the raging, roaring motor cyclist, who seems to glory in the noise he makes. ${ }^{48}$

43 'London's Latest Affliction', Auckland Star, 21 October 1911, 13.

44 'Fair Play', 'The Noisy Motor Cycle Nuisance', Otago Daily Times, 21 February 1928, 5.

45 'Street Noises. Raucous Exhausts. Abatement Solicited. Businessmen's Plaint', Poverty Bay Herald, 19 February

1936, 4 .

46 The Press 4 November 1912, 6; see also Evening Post, 13 December 1912, 6.

47 Manawatu Standard (Palmerston North), 13 April 1926, 6.

48 'Despair', 'A Cruel Infliction', Nelson Evening Mail, 27 September 1926, 10. 
Even before the First World War, an increasingly exasperated tone at the inability of the authorities to suppress the nuisance of noisy motorcycles is detectable in letters to newspapers from correspondents who claimed to represent the suffering, silent majority of the community against 'the perverted outlook of the selfish rackety few' ${ }^{49}$ The problem came to be seen as particularly acute by the mid-1920s, when many local authorities introduced by-laws compelling the use of exhaust silencers. Prosecutions were frequent, and the fines typically varied between 10 shillings and two pounds. ${ }^{50}$ The problem persisted, however, and complaints continued throughout the 1930s; they subsided during the Second World War, only to revive in $1946 .{ }^{51}$ Noisy motorcyclists were difficult to police as, although they drew attention to themselves, they moved quickly enough to evade capture and were difficult to identify at night, when the noise seemed more penetrating. Even in the larger boroughs, traffic inspectors were seldom on duty at night and in any case rarely had motorcycles of their own. ${ }^{52}$ Council meetings, court sessions, concerts and church services were disrupted by the 'dreadful din' of motorcycles. ${ }^{53}$ The offence was compounded by its being quite deliberate: 'youthful riders of motor bicycles' enjoyed 'making all the noise they can, apparently for the purpose of ostentation's4 or 'out of pure "swank". ${ }^{55}$ Not only did the riders' youth and anonymity upset notions of social hierarchy, but the noise they created also undermined deeper concepts of civilisation: in 1926, the president of the Otago Motor Club asked noisy motorcyclists 'to remember that they are in a civilised country, and not in the wilds of Africa or some such place'. ${ }^{56}$

Quietness was a mark of civilisation, and by the mid-1930s it was widely observed that modern cars had become notably less noisy. This was in part due to the more general use of helical gears instead of the straight-cut gears that produced a distinctive howling sound. Noisy car owners were said to 'have neither good taste nor good manners, much less good sense'; these 'vacuous and idle pleasure-seekers' were 'selfish and inconsiderate ... habitually display[ing] the essential qualities of vulgarity—viz., noise, ostentation, and indifference to the feelings of other people. ${ }^{57}$

\footnotetext{
49 'Noisy Motors', Otago Daily Times, 28 October 1913, 4.

50 See, for example, 'Heavy Fines. Many Complaints re Noisy Exhausts', The Press, 28 November 1925, 6.

51 'Peace and Quietness', 'Noisy Motor Cycles', Evening Star (Dunedin), 1 March 1946, 9.

52 Evening Star, 21 October 1926, 11; 'The Exhaust Pest. Worst About Midnight. Council Doing Nothing. No Means of Catching Offenders', Evening Post, 8 April 1927, 10. In Wellington, for instance, the first traffic control motorcycle was acquired in 1928: 'The Sleeper Wakes: Motorcycle Noises', Evening Post, 5 May 1928, 10.

53 Otaki Mail, 16 June 1926, 2; see also 'Noisy Motor Cycle', Northern Advocate, 7 September 1926, 4 (court sitting); 'The World of Music', Auckland Star, 29 October 1932, 23 (concert); Otago Daily Times, 17 November 1926, 16; Minutes of Otago Motor Club 1928-32, 9 April 1929. A.A. Otago records, 95-056 1/9. Hocken Collections (church services).

54 Evening Star, 9 March 1926, 6.

55 'Noise on the Roads', Auckland Star, 23 September 1926, 6.

56 'Noisy Motor-Cyclists', Evening Star, 10 February 1926, 6.

57 'The Menace of Noise', Evening Post, 5 October 1928, 8; 'Motorist and Pedestrian', Evening Star, 27 October 1928, 6 .
} 
Increasingly by the late 1930s the age and decrepitude of noisy cars was emphasised by the press, hinting that their owners similarly were not respectable. ${ }^{58}$ In this, the New Zealand experience resembled the British more than the American. While in the United States discourses about noise 'were dependent on a specifically American politics of racial difference', in Britain, social class was more likely to frame the issue. ${ }^{59}$

The objections to the noise of car horns stemmed from its suddenness and apparent randomness, as well as its ubiquity. Volume was considered less of a problem than the nerve-wracking nature of the sound itself. Many urban by-laws required for safety reasons a warning to be sounded at intersections or blind corners, and when overtaking. To answer the requirement that a horn or hooter be 'efficient', as early as 1916 a range of variously raucous noises was available, from 'a short, deep grunt' to 'a short whistle'. ${ }^{60}$ Complaints at the resulting noise were widespread, and it was argued that the warning sound rapidly lost its effect once it became commonplace, and led to a dangerous sense of complacency on the part of drivers. ${ }^{61}$ Yet if a motorist did not sound the horn and an accident took place, he or she could be held liable. ${ }^{62}$ The practice was not officially suppressed until the Minister of Transport, Bob Semple, took action in 1938, following the well-publicised lead of Britain, Tasmania, parts of the United States and several European countries. ${ }^{63}$ As a Wellington city councillor from 1925, Semple had been prominent in calls for action to suppress motorcycle noise, which he attributed to 'flashness on the part of the road-hogs' ${ }^{64}$ Action against unnecessary noise in general was prompted by overseas examples, not least the establishment in Britain in 1933 of the Anti-Noise League. ${ }^{65}$ The prominent railway engineer Sir Henry Fowler, chairman of the British Ministry of Transport's Noise Abatement Committee, visited New Zealand in 1935 and told Wellingtonians 'Your streets are much too noisy'. ${ }^{66}$

Sounding of horns was regarded as a particular nuisance near hospitals. Drawing on overseas examples, some hospital boards advocated the creation of special 'quiet zones' in adjoining streets. ${ }^{67}$ Road signs asking motorists to drive quietly and slowly past the public hospital in Dunedin, however, made little difference. ${ }^{68}$ Patients may

58 'Noisy Vehicles Annoy Aucklanders', New Zealand Herald, 19 March 1938, 40.

59 Mansell, The Age of Noise, 146.

60 'Motor Alarms: Some Aspects of the Question', The Press, 23 November 1916, 9.

61 'The Hornblowers', Evening Post, 23 February 1938, 13; 'Safety on the Road', Poverty Bay Herald, 12 July 1938,4

62 'Noisy Motorists', Manawatu Standard, 16 November 1929, 14; “'Sound” Driving. Use of the Horn. Signal of Nuisance?', Evening Post, 4 May 1938, 19.

63 'Sounding Horns', New Zealand Herald, 9 July 1938, 16; Bijsterveld, 'The Diabolical Symphony', 55-6.

64 See, for example, 'Something to be Done', Evening Post, 19 August 1927, 8.

65 Mansell, The Age of Noise, 49.

66 'Much Too Noisy', Stratford Evening Post, 11 January 1935, 5.

67 See, for example, Otago Daily Times, 27 November 1925, 8; Minutes of Otago Motor Club 1924-28, 8 November 1927. A.A. Otago records, 95-056 1/8. Hocken Collections; 'Noisy Passers-By: Hospital Patients Disturbed', Evening Star, 25 November 1927, 2. See also Bijsterveld, 'The Diabolical Symphony', 51.

68 Evening Star, 27 June 1932, 8; 'The Modern Cacophony', Otago Daily Times, 25 September 1933, 8. 
not have appreciated the novelty of 1927, a musical horn that played the first two bars of the Dead March from Handel's oratorio Saul. ${ }^{69}$ The local motoring association provided blue flags bearing its initials that could be flown outside private houses when an invalid was in residence, but the effectiveness of these is unknown. ${ }^{70}$

Some observers detected a deeper meaning in motorists' fondness for sounding their horns. An analysis of the problem of 'road hooligans' in late 1925 concluded the

hooting habit is the typical presentation of the motorist's mentality. The road belongs to him; everyone must give way to him, and he yells to make them do it. It is difficult to understand why people should be condemned to tolerate this nuisance without legal remedy. The law would not countenance pedestrians who made a habit of rushing at top speed along crowded pavements yelling to everyone to get out of their way. ${ }^{71}$

The English accountant and writer Stanley Rowland explicitly linked the 'bruital objurgativeness [sic]' of motor horns with 'the influx of semi-barbarous emotional music and dance' from America. 'The spread of jazz music and the like has synchronised with the increase of noise and general lack of restraint in the public, and the deterioration in sobriety of demeanour. ${ }^{32} \mathrm{~A}$ similar lack of restraint was seen in those motorists who sounded their horns in residential areas at night to announce their arrival or departure with 'a persistent toot, toot, toot' ${ }^{73}$

\section{The visual environment}

The growth of motoring quickly was seen to have a detrimental impact on the visual environment also. When in 1940 Viscountess Galway, wife of the Governor General of New Zealand, linked sealed roads with the recent 'uglification' of the countryside, she may have been conveying more a British feeling than a local one. ${ }^{74}$ However, in both countries, roadside advertising aimed at motorists was seen as a major source of visual pollution. Like noise, visual disturbances were tolerated where they were seen as essential or unavoidable. Advertising was perceived as more of a rural problem than an urban one: hoardings were considered much less objectionable in towns than in the country, particularly if they obscured something thought even

\footnotetext{
69 'The Passing Show', Auckland Star, 16 February 1927, 6.

70 'Warnings of Illness', Otago Daily Times, 7 November 1935, 8.

71 'Discipline for Drivers', Evening Star, 31 December 1925, 6, quoting Harold Cox, 'The Problem of the Motorist', The Spectator (London), 31 October 1925, 10. See also Ladd, Autophobia, 70.

72 'Modern Noises. Motor Horns and Jazz. Serious Social Menace', Northern Advocate, 19 January 1924, 12, quoting Stanley Rowland, 'Noise', The Nineteenth Century and After 94, no. 559 (September 1923); Bijsterveld, 'The Diabolical Symphony', 46. Rowland taught accountancy at the London School of Economics: The Palgrave Companion to LSE Economics, ed. Robert A. Cord (London: Palgrave Macmillan, 2018), 91.

73 'Those Motor Horns! How They are Abused', Auckland Star, 25 March 1924, 7; 'Fed-Up', 'Use and Abuse of Motor-Horns', Nelson Evening Mail, 17 June 1927, 3.

74 'Diploma Winners: Centennial Exhibition', New Zealand Herald, 7 March 1940, 2.
} 
uglier, whereas the scenery was considered a major attraction of rural motoring. The early campaign against roadside advertising focused on areas of natural beauty where signs had been attached to trees and bridges or painted on rock faces.

The growth of motoring was thought largely to blame for the spread of roadside advertising, much of it for car-related products and services such as oil and tyres. Yet this targeted advertising attracted criticism as much from motorists as the wider public, and pressure from car-owning consumers was therefore expected to be most effective. ${ }^{75}$ The Auckland Star, for instance, argued in 1932 that as motorists were among the best-organised sections of the community they were therefore well able to make their influence felt. ${ }^{76}$ Attempts to have roadside advertising hoardings removed began in the early 1920s and intensified in the early 1930s, attracting the support of some prominent public figures and gaining a degree of success with oil companies. It was an issue both proponents and opponents of motoring could agree upon. The principal owner of hoardings, however, the government Railways Department, stood firm. Motor clubs joined local councils and civic societies in the campaign to have hoardings removed on both aesthetic and road-safety grounds. The principal safety criticisms were that hoardings obstructed lines of sight for drivers and that signs either distracted motorists or caused them to ignore important warning signs. Aesthetically, objectors complained 'their general glaring effect [was] so annoying to anyone with the slightest idea of the fitness of things in surroundings'; hoardings 'rouse one's ire with their silent shouting'. ${ }^{77}$ Further, the Auckland Automobile Association complained that some advertisers designed their signs to be mistaken for the association's own official signs. ${ }^{78}$

New Zealand motorists were well aware of the campaign against roadside advertising in Britain initiated by the Society for Checking the Abuses of Public Advertising (SCAPA), founded in 1893, which had resulted in the major oil companies agreeing to withdraw their advertising from roadsides. An additional measure was the passage of the Advertisements Regulation Act 1925. The Royal Automobile Club (RAC) had given SCAPA its support during the First World War. ${ }^{79}$ The New Zealand press supported what was seen as the local manifestation of an international campaign by reprinting many stories about the excesses of roadside advertising in the United States, as well as in Britain and even Italy, where the

75 'Hoardings', The Press, 8 December 1930, 10; 'About Hoardings', Ellesmere Guardian (Southbridge), 8 April 1930,4 .

76 'The Roadside Sign', Auckland Star, 7 September 1932, 6.

77 'About Hoardings', 4. In the United States, urban billboards were also associated with the dumping of rubbish and were seen as threats to 'health, beauty, and morality': see Adam W. Rome, 'Coming to Terms with Pollution: The Language of Environmental Reform, 1865-1915', Environmental History 1, no. 3 (1996): 19.

78 'Hideous Signs: Hoardings on the Roads', Auckland Star, 24 March 1931, 15.

79 Piers Brendon, The Motoring Century: The Story of the Royal Automobile Club (London: Bloomsbury, 1997), 188; 'Posters in the Country', The Press, 21 March 1924, 5; 'Beauty Spots Spoiled', New Zealand Herald, 30 May 1924, 6. SCAPA was later renamed the Advisory Council for the Control of Outdoor Advertising. 
Fascist government banned it outright in 1938. There was, however, no equivalent of the American nationwide anti-billboard campaigning organisation, the National Roadside Council. The prominent role of women in the American campaign also appears to have had no New Zealand parallel, yet on the other hand the prominence of motoring organisations in the New Zealand campaign seems not to have been echoed in the United States. ${ }^{80}$

The campaign initiated by the motor clubs had some initial success, particularly with the larger oil companies. It had begun to gather momentum in early 1924 when motor clubs joined the Counties Association to put pressure on advertisers. ${ }^{81}$ The Christchurch morning newspaper pressed resolutely for action against roadside advertising for many years. Reporting the withdrawal of advertising by major oil companies in Britain in early 1924, The Press urged New Zealand automobile associations to follow the RAC's example and become 'the unofficial protector[s] of country roads' from the 'unconscious vandal'. ${ }^{82}$ The Marlborough Automobile Association was credited with having first taken up the call for a campaign against roadside advertising a few months later. ${ }^{83}$ The South Island Motor Union (SIMU) sent a deputation to the New Zealand Motor Trade Conference in September 1924 to ask that its members advertise 'in an ethical way', and was given an undertaking that the trade would assist in prohibiting objectionable rural advertising. ${ }^{84}$ It went on to gain the support of other regional motor clubs in the SIMU for a ban. ${ }^{85}$ Firms that supplied motorists were the most susceptible to pressure, but the line taken by motoring organisations could be undermined by their journals' reliance on advertising. The official journal of the SIMU, for instance, carried large advertisements on its front cover in 1929 depicting roadside signs for Big Tree petrol. One showed the firm's name painted on a large boulder with the caption, apparently not intended ironically, 'Do you know where this is?' ${ }^{86}$ Another showed a rubble-strewn field with a water tank covered in advertising for Big Tree, blocking a view of Lake Pukaki and accompanied by the slogan 'A delightful place to stay'. To present-day eyes, this could easily be mistaken for an advertisement campaigning against roadside advertising. ${ }^{87}$

\footnotetext{
80 See Catherine Gudis, Buyways: Billboards, Automobiles, and the American Landscape (New York and London: Routledge, 2004), 163-81.

81 'Beauty Spots Spoiled', New Zealand Herald, 30 May 1924, 6.

82 'Roadside Advertising', The Press, 21 February 1924, 8.

83 'Roadside Advertisements: Objectionable Signs', The Press, 20 May 1925, 4.

84 'Rural Advertising: Defacing Beauty Spots', Auckland Star, 9 October 1924, 8.

85 'Beauty Spots Spoiled', New Zealand Herald, 30 May 1924, 6.

86 The New Zealand Motor Owner 1, no. 10 (16 September 1929): [1].

87 The New Zealand Motor Owner 1, no. 12 (15 November 1929): [1].
} 
The effect of voluntary bans proved only temporary, prompting the SIMU to write to its constituent clubs in 1931 urging them to press their local councils to take action on the issue. ${ }^{88}$ Local beautifying societies approached motor clubs for their support in the campaign. ${ }^{89}$ The clubs lobbied their members of parliament to support legislation to allow county councils to ban roadside hoardings. ${ }^{90}$ Motoring organisations were able to place effective pressure on some of the more prominent advertisers. In response to a request by the SIMU, the Vacuum Oil Company in 1927 declared its opposition to 'the erection of advertising material in or about rural districts which would tend to disfigure or mar the natural beauties' and would in future confine its advertising to the vicinity of towns. ${ }^{91}$ This echoed the move by its former owner Standard Oil in the United States in 1924, and was followed by the other oil companies operating in New Zealand. ${ }^{92}$ Yet the campaign against other advertisers continued, and in 1929 the North and South Island Motor Unions made a combined representation to the government to introduce legislation to ban all roadside advertising, a demand they repeated in 1930 and $1931 .{ }^{93}$ Eventually, in 1932, the North Island Motor Union (NIMU) appointed a special committee to frame legislation to meet the 'evil'. ${ }^{4}$

Though it made little progress with the national government, local councils were more receptive to the campaign. Without national legislation, however, they were unable to take legal action against hoardings on private property, and land owned by the crown was exempt from council by-laws. The Railways Department was particularly recalcitrant, telling a deputation from the Oamaru Beautifying Society that a particular hoarding would 'improve the locality'. ${ }^{95}$ For its part, the Association of New Zealand Advertisers argued that well-designed hoardings were of value in hiding offensive places or ugly buildings, though it agreed they should be banned in the country where they would mar the landscape. ${ }^{96}$ The campaign against roadside advertising attracted a great deal of respectable support, not least from the Governor-General, Lord Bledisloe, who in 1932 secured an assurance from the oil companies that they would remove their advertising from country roads. ${ }^{97}$

88 'Roadside Hoardings: Defacing the Countryside', Ellesmere Guardian (Southbridge, Canterbury), 10 April 1931, 8 .

89 New Zealand Herald, 14 April 1927, 16.

90 New Zealand Parliamentary Debates vol. 214 (Wellington: Government Printer, 1927), 326 col. 1.

91 'Roadside Hoardings', New Zealand Herald, 21 February 1927, 14.

92 Gudis, Buyways, 178-9; The New Zealand Motor Owner 1, no. 2 (15 January 1929): 3.

93 'Roadside Hoardings: Request for Abolition', Auckland Star, 12 March 1929, 8; 'Viewed With Alarm: Dangerous Hoardings', Evening Post, 8 December 1930, 13; 'Rural Hoardings', Auckland Star, 16 December 1931, 10.

94 'The Roadside Sign', Auckland Star, 7 September 1932, 6.

95 'Roadside Hoardings', Auckland Star, 28 January 1927, 6.

96 'Roadside Hoardings', New Zealand Herald, 16 February 1933, 14.

97 'Defacing the Landscape', New Zealand Herald, 2 July 1932, 8; 'Roadside Hoardings: Disfiguring Country', New Zealand Herald, 7 September 1932, 8; 'Signs on Roadside: Efforts at Removal', New Zealand Herald, 21 October 1932, 12. On his return home to Cirencester, Bledisloe became President of the Gloucestershire branch of the Council for the Protection of Rural England: David Jeremiah, 'Motoring and the British Countryside', Rural History 21, no. 2 (2010): 248. 
There were some limited local successes for motor clubs. The Marlborough Automobile Association gained the willing support of the county council to remove roadside advertising in 1931, though it had no power over signs on private land.98 The Auckland Automobile Association approached local businesses in 1932 and persuaded them to withdraw their advertisements from hoardings along a newly built stretch of a major highway south of the city. ${ }^{99}$ Shell Oil, which had withdrawn its roadside advertising in Britain in 1924, finally did so in New Zealand in 1932. ${ }^{100}$

The campaign prompted at least one case of direct action against roadside advertising. Protests against unsightly signs in a picturesque river valley in Central Otago had been made to the Minister of Railways without success by a range of regional promotional and environmental associations, including the Otago Motor Club, the Otago Expansion League, the Amenities and Town Planning Society, the Native Bird (from 1935 Forest and Bird) Protection Society, and the Otago Institute, the principal provincial scientific body. Frustrated at what they saw as the government's lethargic indifference to hoardings in areas of natural beauty, 'an intolerable outrage' that made 'the country hideous', a group of respectable professional men from Dunedin set off inland in 1930 to 'clean up' the picturesque Kawarau Gorge. Three of them were medical practitioners, including a 65-year-old professor at the University of Otago Medical School, a prominent member of the Otago Motor Club and the Amenities Committee of the Expansion League who had been protesting against roadside hoardings since at least $1920 .{ }^{101}$ ' $[\mathrm{I}]$ ntoxicated with zeal', they cut down five signs, including a large railway-owned hoarding, which they thought 'desecrated a particularly fine piece of scenery'. ${ }^{102}$ Convicted and fined for wilful damage, they explained their motivation:

Our scenic routes are strewn with placards, sheds and roofs of buildings are daubed with advertisements, even, the trees, fences, and rocks are not immune. The craze for advertising has reached such a pitch that no place is sacred; the greater the natural charm, the more opportunity for vulgar display ... Surely the road users have some rights. ${ }^{103}$

98 'Roadside Hoardings', The Press, 16 November 1931, 7.

99 'Roadside Hoardings', Auckland Star, 18 October 1932, 14.

100 'Unsightly Hoardings', Evening Post, 29 September 1932, 10.

101 F. R. Riley, 'Advertising Hoardings', Otago Daily Times, 12 May 1920, 9; Minutes of Otago Motor Club 1924-28, 3 October 1925, 'Advertising Signs'. A.A. Otago records, 95-056 1/8. Hocken Collections; 'Otago Motor Club', Otago Daily Times, 9 July 1930, 3.

102 'Aesthetic Protest. Unsightly Hoardings. Iconoclastic Activity', Evening Post, 18 September 1930, 14; 'Raid on Hoarding', Auckland Star, 17 October 1930, 9; 'Despoiling Rural Scenery', Otago Daily Times, 18 October 1930, 10.

103 'Rural Advertising', Otago Daily Times, 24 November 1930, 6. 
Despite the widespread support for the campaign against roadside advertising, success was limited, and on the eve of the Second World War the national conference of beautifying societies still felt the need to urge the government to control advertising hoardings. ${ }^{104}$ A delegate to the NIMU in 1939 identified the fundamental conflict between the motorists' policy and the Railways Department's: the motorists put up warning signs at dangerous places, while the department put up 'distracting advertisements'. In Christchurch, the editor of The Press 'deplored ... the fact that the activity and influence of the Railway[s] Department have unquestionably prevented reform while they have extended the mischief'. The railways had made a profit of $£ 18,000$ from roadside advertising over the previous seven years, so had a clear motive for resisting the attempts of the Internal Affairs Department to restrict the 'undesirable enterprise'. ${ }^{105}$ The Canterbury Roadside Beautifying Association had made no progress with the newly appointed Minister of Railways in 1936, even though, when in his previous position as Mayor of Christchurch, Dan Sullivan had expressed his opposition to the department's roadside hoardings. ${ }^{106}$ As the president of the Marlborough Automobile Association had put it in 1930, the state was one of the worst offenders with regard to advertising hoardings: 'The others mostly are amenable to reason, but you can't get any reason out of the State. ${ }^{107}$ The question was not to be resolved until well after the Second World War. ${ }^{108}$

\section{Conclusion}

Early motor cars were regarded as being more of an assault on the human senses than on the environment as such, though it was one that was difficult to quantify. The noises they made could affect anyone, anywhere. Exhaust fumes, though a nuisance to the public, were seen largely as a danger only to the incautious motorist. Motorists themselves were also at the forefront of complaints about the harm done to the visual environment indirectly by the growth of motoring. In each of these concerns, New Zealand opinion drew on and was primed by international experience. Newspapers were particularly important in this process, but the cultural conduit provided by such figures as the governor-general also played a part. Noise in particular fitted into an international discourse on the nature of the modern world: technological advances were making the world a noisier place, but not all noises had to be tolerated in the name of progress. Noisy cars and motorcycles

104 'Roadside Hoardings', Evening Post, 15 August 1939, 5.

105 'Hoardings', The Press, 18 March 1939, 16.

106 'Advertising by Hoardings', The Press, 16 December 1936, 10.

107 'Roadside Hoardings', Evening Post, 3 December 1930, 7.

108 A private member's Hoardings Bill was introduced in 1948, but was heavily defeated. Opponents argued that the proposed ban would harm commercial interests, but also that 'many hoardings were attractive and helped to mould better public opinion': 'Hoardings Bill: Private Interests Affected', Otago Daily Times, 5 August 1948, 5. See also Tony Nightingale and Paul Dingwall, Our picturesque heritage: 100 years of scenery preservation in New Zealand (Wellington: Department of Conservation, 2003). 
were joined by speedboats, radio loudspeakers and pneumatic drills as sources of complaint in the course of the 1920s. In the case of noisy motorcyclists, a hyperbolic sense of powerlessness on the part of the respectable members of society was coupled with the feeling that the social hierarchy was being challenged by the youthful and uncivilised. While visual pollution and some forms of noise pollution remained intractable problems, others seemed to have been resolved by the end of the interwar period. Cars had become much quieter, and their drivers had been induced to desist from honking their horns. Concerns regarding vehicle emissions were still far in the future. 
This text is taken from International Review of Environmental History, Volume 6, Issue 1, 2020, edited by James Beattie, published 2020 by ANU Press, The Australian National University, Canberra, Australia.

doi.org/10.22459/IREH.06.01.2020.02 